\title{
Analisa ketersedian uang di mesin ATM mengunakan Algoritma C4.5
}

\author{
Deval Gusrion \\ Universitas Putra Indonesia"YPTK” Padang, Indonesia \\ devalgusrion@gmail.com
}

\begin{abstract}
Ketersediaan uang merupakan salah satu faktor yang paling penting dalam kualitas layanan di mesin ATM. Kebutuhan uang disetiap mesin ATM berbeda-beda sesuai dengan lokasi penepatan mesin ATM selain itu disebabkan juga oleh faktor musiman misalnya pada hari besar, hari libur atau weekend sehingga banyak terjadi transaksi penarikan uang tunai yang melebihi dari transaksi yang terjadi pada hari biasanya. Dengan menggunakan metode algoritma C4.5 untuk prediksi durasi waktu uang cashout (uang habis) dalam caset/kas ATM dapat membantu tim tambahan kas untuk memprediksi perkiraan waktu dan jumlah uang yang akan disediakan untuk pengisian uang berikutnya sehingga dapat meningkatkan kinerja dan kualitas pelayanan di mesin ATM.
\end{abstract}

Keyword : Data Mining, Algoritma C4.5, Mesin ATM, Uang, Bank

\begin{abstract}
Abstrak
Ketersediaan uang merupakan salah satu faktor yang paling penting dalam kualitas layanan di mesin ATM. Kebutuhan uang disetiap mesin ATM berbeda-beda sesuai dengan lokasi penepatan mesin ATM selain itu disebabkan juga oleh faktor musiman misalnya pada hari besar, hari libur atau weekend sehingga banyak terjadi transaksi penarikan uang tunai yang melebihi dari transaksi yang terjadi pada hari biasanya. Dengan menggunakan metode algoritma C4.5 untuk prediksi durasi waktu uang cashout (uang habis) dalam caset/kas ATM dapat membantu tim tambahan kas untuk memprediksi perkiraan waktu dan jumlah uang yang akan disediakan untuk pengisian uang berikutnya sehingga dapat meningkatkan kinerja dan kualitas pelayanan di mesin ATM.
\end{abstract}

Kata kunci : Data Mining, Algoritma C4.5, Mesin ATM, Uang, Bank

\section{PENDAHULUAN}

Di era milenial sekarang teknologi informasi terus berkembang, seiring dengan bertambahnya data dalam jumlah yang sangat besar atau yang kita kenal dengan istilah gudang data/basis data. Data merupakan sumber daya yang sangat berharga dalam menghasilkan sebuah informasi untuk mengambil keputusan. Dengan jumlah data yang sangat besar tersebut, data memerlukan sebuah metode/ilmu dan teknologi informasi yang tepat untuk mengolahnya, karena kebutuhan akan informasi yang cepat dan akuran sangat penting dalam mengambil keputusan.

Metode atau ilmu yang muncul untuk mengelola dan menyaring data yang besar dikenal dengan istilah data minning. Data mining adalah campuran dari statistic, kecerdasan buatan, dan riset basis data yang masih berkembang [1]. Data mining merupakan suatu alat yang memungkinkan para pengguna (user) untuk mengakses data secara cepat dengan jumlah yang besar, data mining juga dikenal sebagai knowledge discovering atau knowledge extracting [2].

Teknik-teknik yang digunakan untuk pengekstrakan pengetahuan dalam data mining adalah pengenalan pola, clustering, asosiasi, prediksi dan klasifikasi. Klasifikasi merupakan salah satu 
topik utama dalam data mining atau machine learning, klasifikasi mengelompokan data dimana data yang digunakan tersebut mempunyai kelas label atau target. Klasifikasi mempelajari pola-pola dari data historis (sekumpulan informasi -seperti ciri-ciri, variabel-variabel, fitur-fitur) dengan tujuan untuk menempatkan instans (object-object) baru (dengan label yang tak diketahui sebelumnya) ke dalam kelompok atau kelas masing-masing, dan teknik klasifikasi yang digunakan salah satunya adalah algoritma C4.5.

Manajemen kas yang optimal dan ketersediaan layanan merupakan salah satu faktor yang paling penting dalam bisnis layanan jaringan ATM [9]. Kebutuhan uang setiap mesin bisa berbeda-beda sesuai dengan lokasi mesin ATM, mesin ATM yang berada dipusat pembelanjaan akan lebih tinggi transaksinya dibandingkan ATM yang di tempatkan di lokasi yang bukan pusat pembelanjaan, selain itu disebabkan oleh faktor musiman misalnya pada bulan ramadhan, hari besar, hari libur, atau weekend sehingga banyak terjadi transaksi tunai yang melebihi dari transaksi yang terjadi pada hari biasa. Kebutuhan uang setiap ATM nantinya disesuaikan dengan tingkat fluktuatif penarikannya sehingga dapat meminimalisir banyaknya uang yang menganggur di ATM terlalu lama karena uang tersebut dapat diputar untuk proses bisnis yang lain oleh bank.

Algoritma C4.5 pada penelitian ini digunakan untuk memprediksi jumlah kas (uang) yang akan disediakan serta memprediksi waktu pengisihan kas berikutnya untuk masing-masing ATM dengan mengambil sampel data beberapa mesin ATM di salah satu perbankan yang ada di Kota Padang. Pengunaan metode algoritma C4.5 ini diharapkan dapat membantu tim tambahan kas untuk memprediksi perkiraan waktu pengisian uang berikutnya sehingga dapat mengantisipasi uang cashout (uang habis) dalam caset/kas ATM dan diharapkan juga penelitian ini akan menghasilkan analisa untuk memprediksi jumlah kas ATM yang akan disediakan untuk pengisihan uang berikutnya sehingga dapat meningkatkan kinerja dan kualitas pelayanan ATM.

\section{Tinjauan Literatur}

Dalam penulisan jurnal ini, beberapa hal-hal atau teori yang dikemukakan yang berkaitan dengan permasalahan dan ruang lingkup sebagai landasan dalam permbuat jurnal seperti : pemodelan dan UML, data minning, knowledge discovery in Database (KDD), pohon keputusan dan algoritma C4.5, yang bersumber dari buku, jurnal-jurnal penelitian yang telah lebih dahulu dilakukan oleh peneliti lain.

\subsection{Pemodelalan dan UML}

Unified Modeling Language (UML) merupakan salah satu alat bantu yang dapat digunakan dalam bahasa pemograman yang berorientasi objek. UML (Unified Modeling Language) yaitu keluarga notasi grafis yang didukung oleh meta-model tunggal, yang membantu pendeskripsian dan desain sistem perangkat lunak, khususnya sistem yang dibangun dengan menggunakan pemrograman berorientasi objek [4]. 


\subsection{Data Minning}

Data mining merupan suatu alat yang memungkinkan para pengguna untuk mengakses secara cepat data dengan jumlah yang besar. Data Mining juga merupakan suatu proses penggalian data atau penyaringan data dengan memanfaatkan kumpulan data dengan ukuran yang cukup besar melalui serangkaian proses untuk mendapatkan informasi yang berharga dari data tersebut. Data Mining dapat diterapkan pada berbagai bidang yang mampunyai sejumlah data. Menurut Daryl Pregibon bahwa "Data mining adalah campuran dari statistic, kecerdasan buatan, dan riset basis data" yang masih berkembang [1].

Data mining memungkinkan pemakai menemukan pengetahuan dalam data database yang tidak mungkin diketahui keberadaanya oleh pemakai, Istilah lain yang sering digunakan diantaranya knowledge discovery (mining) in databases (KDD).

\subsection{Knowledge Discovery in Database}

Knowledge Discovery in Database (KDD) adalah proses menentukan informasi yang berguna, Informasi ini terkandung dalam basis data yang berukuran besar yang sebelumnya tidak diketahui namun memiliki potensial dan bermanfaat, dengan proses yang bantu oleh komputer untuk menggali dan menganalisis sejumlah besar himpunan data dan mengekstrak informasi sehinga diperoleh pengetahuan yang berguna.

Pada proses KDD terdapat 5 tahapan (Nofriansyah dan Nurcahyo,2017)[1], yaitu sebagai berikut :

1. Seleksi Data (Data selection) : merupakan tahap awal dalam KDD yaitu penyeleksian sekumpulan dari data yang digunakan untuk proses data mining, yang nantinya data tersebut akan dikumpulkan dalam suatu berkas, tapi data tersebut terpisah dari basis data operasional.

2. Pemilihan Data (Pre-processing/Cleaning) : tahapan ini merupakan proses data cleaning meliputi yaitu pembuangan data-data yang redudan atau pembuangan duplikasi data, datadata yang tidak konsisten juga akan diperiksa pada tahap ini, serta kesalahan yang terdapat pada data diperbaiki ditahap ini seperti kesalahan ceta (tipografi). Selain itu dilakukan proses enrichment yaitu proses memperkaya data yang sudah ada dengan data atau informasi lain yang relevan dan diperlukan untuk KDD seperti data atau informasi eksternal.

3. Transformasi (Transformation) : tahap ini data diubah kedalam bentuk yang sesuai untuk mining coding adalah proses transformasi pada data yang telah dipilih. Proses coding dalam KDD merupakan proses kreatif dan sangat tergantung pada jenis atau pola informasi yang akan dicari dalam basis data.

4. Data mining : proses mencari pola atau informasi menarik dalam data yang terplih dengan menggunakan teknik atau metode tertentu. Pemilihan metode atau algoritma yang tepat sangat bergantung pada tujuan dari proses KDD secara keseluruhan.

5. Interpretation/Evaluation : tahap ini mencakup pola atau informasi yang ditemukan bertentangan dengan fakta atau hipotesa yang ada sebelumnya.

\subsection{Pohon Keputusan}

Pohon keputusan adalah model prediksi menggunakan struktur pohon atau struktur berhirarki. Menurut [1] pohon keputusan (decision tree) dapat membagi kumpulan data yang besar (learning dataset) menjadi himpunan-himpunan record yang lebih kecil dengan menerapkan serangkaian aturan keputusan (rules), sehingga anggota himpunan hasil menjadi mirip satu dengan lainnya 
dengan memperhatikan pada variabel tujuannya (target variable). Decision tree merupakan salah satu metoda klasifikasi data mining yang popular digunakan karena mudah diinterprestasikan oleh manusia dengan konsep dasar mengubah data menjadi pohon keputusan dan aturan-aturan keputusan [10].

Konsep dari pohon keputusan adalah mengubah data menjadi pohon keputusan dan aturan-aturan keputusan.

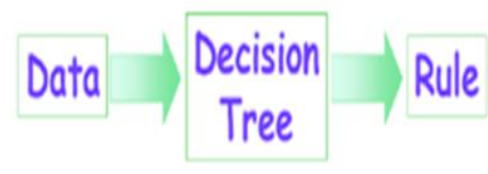

Gambar 1. Konsep Pohon Keputusan/Decision Tree

Data dalam pohon keputusan biasanya dinyatakan dalam bentuk tabel dengan atribut dan record. Atribut menyatakan suatu parameter yang dibuat sebagai kriteria dalam pembentukan tree.

\subsection{Algoritma C.45}

Algoritma C4.5 atau disebut juga sebagai algoritma decision tree merupakan metode klasifikasi dan prediksi yang sangat kuat dan terkenal. Algoritma ini termasuk metode Data Mining, yang merupakan proses menemukan pola dengan memilah-milah sejumlah data yang besar menggunakan teknologi pengenalan pola (Kamagi et.al, 2014).. Secara umum Algoritma C4.5 untuk membangun pohon keputusan adalah sebagai berikut:

1. Pilih atribut sebagai akar

2. Buat cabang untuk masing-masing nilai

3. Bagi kasus dalam cabang

4. Ulangi proses untuk masing-masing cabang sampai semua kasus pada cabang memiliki kelas yang sama

Untuk menghitung algoritma C4.5, maka harus mencari nilai entropy dan information gain.Dimana nilai entropy adalah pengukuran ketidakpastian, di mana semakin tinggi entropy, maka semakin tinggi ketidakpastian[11]. Entropy (S) merupakan jumlah bit yang diperkirakan dibutuhkan untuk dapat mengekstrak suatu kelas (+ atau -) dari sejumlah data acak pada ruang sampel S. Entropy dapat dikatakan sebagai kebutuhan bit untuk menyatakan suatu kelas. Entropy digunakan untuk mengukur ketidakaslian S.

Rumus entropy dapat dilihat pada persamaan 1.

$$
\text { Entropi }(R)=\sum_{i=0}^{a}-k i * \log _{2} k i
$$

Di mana:

$$
\begin{aligned}
& R=\text { himpunan kasus. } \\
& a=\text { jumlah partisi } R \\
& k_{i}=\text { proporsi } R \text { pada partisi ke- } i
\end{aligned}
$$

setelah menghitung entropy suatu kumpulan data, selanjutnya kita dapat mengukur seberapa efektifnya atribut dari data tersebut dalam mengklasifikasikan data, yang disebut juga dengan information gain [11]. Untuk menentukan nilai gain dapat dilihat dari persamaan 2 berikut ini : 


$$
\operatorname{Gain}(T, W)=\operatorname{Entropy}(R) \sum_{i=0}^{a}-\frac{|R i|}{|R|} * \text { Entropy }(k i)
$$

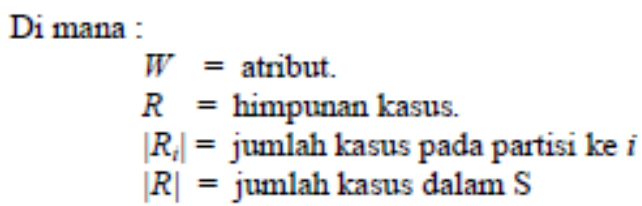

\section{Metodologi Penelitian}

Metodologi penelitian yang digunakan meliputi Studi literatur dengan teknik mengumpulkan data atau informasi dari bagian terkait di perbankan, kemudian diolah dengan mengunakan konsep yang ada pada algoritma c.45, adapun tahapan seperti :

1. Tahap mengklasifikasikan data

Pada tahap ini setiap data dikelompokkan, dimana transaksi penarikan uang disetiap mesin ATM yang sudah ditotalkan dikelompokan berdasarkan kriteria waktu dan jumlah penarikan.

2. Menghitung nilai entropi

Setelah memperoleh data analisis ketersediaan uang dimasing-masing ATM berdasarkan report penarikan uang secara tunai, langkah selanjutnya adalah menghitung nilai entropy, yang mana nilai entropy ini digunakan untuk mencari nilai gain.

3. Menghitung Nilai Gain

Setelah mendapat nilai entropy selanjutnya dicari nilai gain, nilai gain ini nantinya digunakan untuk menentukan atribut akar untuk pembuatan decision tree.

4. Menentukan Atribut Root

Setelah didapat nilai gain untuk setiap kriteria, selanjutnya akan ditentukan kriteria yang akan menjadi atribut root pada pembentukan tree dengan ketentuan kriteria dengan nilai gain yang tertinggi yang menjadi atribut root.

5. Membuat Decision Tree

Setelah didapat atribut root, kemudian dibuatlah pohon keputusan untuk kriteria yang dengan nilai gain tertinggi. Untuk mendapatkan pohon keputusan dari penentuan dari transaski di mesin ATM yang telah dikelompakan bersarkan kritria penarikan uang, maka harus dicari kembali nilai entropy dan gain dari setiap atribut.

6. Membuat cabang setiap kasus

Tahapan ini dilakukan dengan mengulangi proses perhitungan Entropy dan Gain untuk mencari cabang sampai semua kasus pada cabang memiliki kelas yang sama yaitu pada saat semua variabel telah menjadi bagian pohon keputusan (daun).

7. Membuat rule berdasarkan pohon keputusan

Setelah dibuat pohon keputusan sehingga semua atribut-atribut yang ada pada setiap kasus sudah tergambar akan tampak rule yang akan kita gunakan untuk pengambilan keputusan dalam penentuan persediaan uang di setian mesin ATM

8. Implementasi

Sistem yang dirancang mengunakan bahasa pemograman dengan metode-metode yang mengacu pada algoritma c. 45 


\section{Hasil dan Diskusi}

Setelah dilakukan tahapan analisis dan perancangan, untuk menampilkan hasil analisa dari penelitian ini apakah sesuai dengan tujuan, maka perlu dilakukannya implementasi dan pengujian pada penelitiian ini, di mana mengimplementasikan hasil yang telah dianalisis dan dirancang sebelumnya. Adapun tahapan-tahapan implementasi tersebut berupa spesifikasi implementasi perangkat keras dan spesifikasi pengujian perangkat lunak.

Data pada penelitian ini telah dianalisa yang berasal dari sampel dari beberapa mesin ATM (12 mesin ATM) dari sebuah industri jasa keuangan yang ada di Provinsi Sumatera barat. Diketahui data set dapat dilihat dari tabel dibawah ini :

Tabel 2 : Dataset Mesin ATM

\begin{tabular}{|c|c|c|c|c|c|c|c|}
\hline No & TID & $\begin{array}{c}\text { Pusat } \\
\text { Keramaian }\end{array}$ & $\begin{array}{c}\text { Tingkat } \\
\text { Kerusakan }\end{array}$ & $\begin{array}{l}\text { Listrik } \\
\text { Padam }\end{array}$ & $\begin{array}{c}\operatorname{tr} x> \\
300 / \text { hari }\end{array}$ & $\begin{array}{l}\text { Sering Cashout } \\
\qquad(<2 \text { hari) }\end{array}$ & $\begin{array}{l}\text { Tambahan Kas } \\
\text { ATM ( }<2 \text { hari) }\end{array}$ \\
\hline 1 & 12045 & $\mathrm{Ya}$ & Jarang & Jarang & Tidak & Tidak & $\mathrm{Ya}$ \\
\hline 2 & 12056 & $\mathrm{Ya}$ & Sering & Jarang & Tidak & Ya & Tidak \\
\hline 3 & 12067 & $\mathrm{Ya}$ & Jarang & Jarang & $\mathrm{Ya}$ & Tidak & $\mathrm{Ya}$ \\
\hline 4 & 12068 & $\mathrm{Ya}$ & Jarang & Sering & Ya & Tidak & $\mathrm{Ya}$ \\
\hline 5 & 12069 & $\mathrm{Ya}$ & Jarang & tidak ada & $\mathrm{Ya}$ & Tidak & Tidak \\
\hline 6 & 12071 & Tidak & Jarang & jarang & Tidak & Tidak & $\mathrm{Ya}$ \\
\hline 7 & 12070 & Tidak & Sering & Sering & $\mathrm{Ya}$ & $\mathrm{Ya}$ & Tidak \\
\hline 8 & 12078 & $\mathrm{Ya}$ & Jarang & Jarang & $\mathrm{Ya}$ & Tidak & $\mathrm{Ya}$ \\
\hline 9 & 12080 & Tidak & Sering & Jarang & $\mathrm{Ya}$ & $\mathrm{Ya}$ & Tidak \\
\hline 10 & 12077 & $\mathrm{Ya}$ & Sering & Sering & $\mathrm{Ya}$ & Ya & Tidak \\
\hline 11 & 12089 & $\mathrm{Ya}$ & Jarang & Jarang & Tidak & Tidak & $\mathrm{Ya}$ \\
\hline 12 & 12087 & Tidak & Jarang & Jarang & Tidak & Tidak & $\mathrm{Ya}$ \\
\hline
\end{tabular}

Dari tabel diatas terdapat 7 atribut (tid, pusat keramaian, tingkat kerusakan, listrik padam, trx > 300/hari, cashout dan tambahan kas). Kelas Tambahan kas $<2$ hari terdiri dari record "Ya" dan "tidak", jumlah data sebanyak 12 terdiri dari $\mathrm{Ya}=7$ dan tidak=5.

1. Entropy Total Dataset

$$
S=\left\{-\frac{7}{12} *\left(\log 2\left(\frac{7}{12}\right)\right)\right\}+\left\{-\frac{5}{12} *\left(\log 2\left(\frac{5}{12}\right)\right)\right\}=0,9798687107
$$

2. Entropy dan gain tiap atribut

$$
\begin{aligned}
& \text { Entrophy [ Pusat keramaian - Ya }] \\
& S=\left\{-\frac{5}{8} *\left(\log 2\left(\frac{5}{8}\right)\right)\right\}+\left\{-\frac{3}{8} *\left(\log 2\left(\frac{3}{8}\right)\right)\right\}=0,954434003 \\
& \text { Entrophy [ Pusat keramaian- Tidak] } \\
& S=\left\{-\frac{2}{4} *\left(\log 2\left(\frac{2}{4}\right)\right)\right\}+\left\{-\frac{2}{4} *\left(\log 2\left(\frac{2}{4}\right)\right)\right\}=1 \\
& \text { Gain [ Pusat keramaian ] = 0,9798687107-\{ } \left.\frac{8}{12} * 0,954434003\right\}+\left\{\frac{4}{12} * 1\right\}=0,0102460421
\end{aligned}
$$


Entrophy [ Listrik padam - Rutin ]
$S=\left\{-\frac{6}{8} *\left(\log 2\left(\frac{6}{8}\right)\right)\right\}+\left\{-\frac{2}{8} *\left(\log 2\left(\frac{2}{8}\right)\right)\right\}=0,8112781243$
Entrophy [ Listrik padam - Jarang
$S=\left\{-\frac{1}{3} *\left(\log 2\left(\frac{1}{3}\right)\right)\right\}+\left\{-\frac{2}{3} *\left(\log 2\left(\frac{2}{3}\right)\right)\right\}=0,9182958338$
Entrophy [ Listrik padam - Tidak ada ] =0
Gain [ Listrik ] = 0,9798687107 - $\left\{\frac{8}{12} * 0,8112781243\right\}+\left\{\frac{3}{12} * 0,9182958338\right\}+\left\{\frac{1}{12} * 0\right\}=0,2094410656$

$S=\left\{-\frac{4}{5} *\left(\log 2\left(\frac{4}{5}\right)\right)\right\}+\left\{-\frac{1}{5} *\left(\log 2\left(\frac{1}{5}\right)\right)\right\}=0,7219280947$

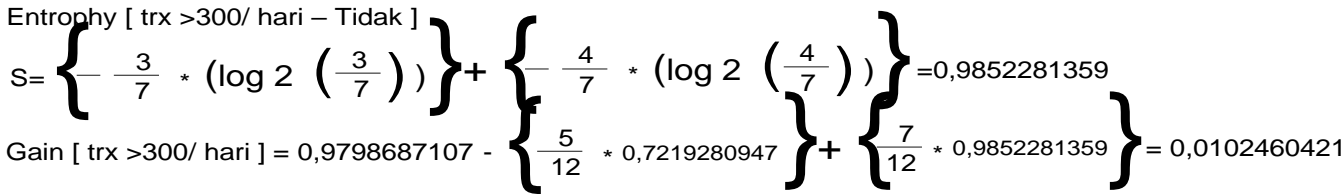

$S=\left\{-\frac{7}{8} *\left(\log 2\left(\frac{7}{8}\right)\right)\right\}+\left\{-\frac{1}{8} *\left(\log 2\left(\frac{1}{8}\right)\right)\right\}=0,5435644433$

$\left.\begin{array}{l}\text { Entrophy [ Cash out }- \text { Tidak ] }=0 \\ \text { Gain [ Cash out ] }=0,9798687107-\left\{\frac{8}{12} * 0,5435644433\right.\end{array}\right\}+\left\{\frac{4}{12} * 0\right\}=0,6174924154$

Hitung total jumlah data untuk setiap atribut nilai kelas =

Cashout rendah $=8$

Cashout tinggi $=4$

TID : 12071

Cashout rendah $=\mathrm{Ya}$

Cashout tinggi $=$ Tidak

$\operatorname{tr} x>300=$ tidak

Pusat keramaian $=\mathrm{Ti}$..

Tambahan kas ATM $<2$ hari $=$ Tid. .

Caset kosong dalam $<2=1$

SIMPAN KELUAR

CETAK

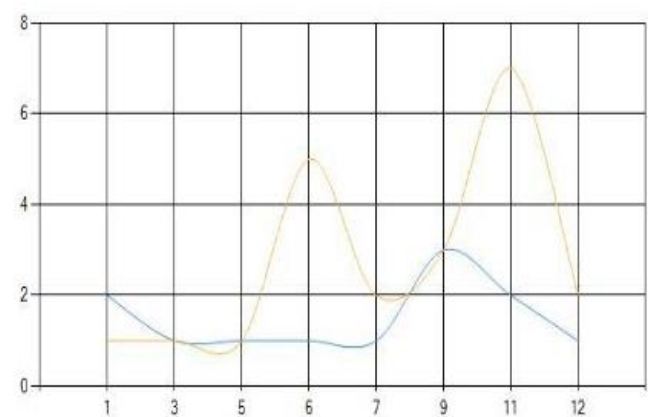

Gambar 6 : Form prediksi

\section{Kesimpulan}

Kesimpulan yang dapat dikemukakan dari analisa ketersedian uang di mesin ATM mengunakan Algoritma C4.5 berdasarkan hasil analisis data dan pengujian dapat ditarik beberapa kesimpulan sebagai berikut :

a. Analisa ketersediaan uang mengunakan algoritma C4.5 dapat membantu tim tambahan kas untuk memprediksi perkiraan waktu untuk pengisian uang berikutnya, sehingga dapat mengantisipasi uang cashout (uang habis) dalam caset/kas ATM.

b. Dengan adanya analisa ketersediaan uang dengan mengunakan algoritma C4.5 tim tambahan kas dapat memprediksi jumlah kas ATM yang akan disediakan untuk pengisihan uang berikutnya. 


\section{Referensi}

[1] Nofriansyah, D., And Nurcahyo, G, W. (2017). “Algoritma Data Mining Dan Pengujian”.

[2] Gorunescu, F. (2011). Data Mining : Concepts, Models and Techniques. New York: Springer-Verlag.

[3] Tampubolon, K., Saragih, H., Reza, B., Epicentrum, K., Asosiasi, A., \& Apriori, A. (2013).

Implementasi Data Mining Algoritma Apriori Pada Sistem Persediaan Alat-Alat Kesehatan. Informasi Dan Teknologi Ilmiah, 93.

[4] Fowler, Martin," UML Distilled : Panduan Singkat Bahasa Pemodelan Objek Standar," Yogyakarta: Andi,2005.

[5] Tampubolon, K., Saragih, H., Reza, B., Epicentrum, K., Asosiasi, A., \& Apriori, A. (2013). Implementasi Data Mining Algoritma Apriori Pada Sistem Persediaan Alat-Alat Kesehatan. Informasi Dan Teknologi Ilmiah, 93-106. https://doi.org/2339-210X.

[6] Witten, I. H., Frank, E., Hall, M. A., 2011, Data Mining Practical Machine Learning Tools and Techniques (3rd ed). USA: Elsevier.

[7] Berry, Michael J.A dan Gordon S. Linoff., 2004, Data Mining Techniques for Marketing, Sales, Customer Relationship Management, Second Edition, Willey Publishing, Inc.

[8] Kamagi, et.al, 2014 Implementasi Data Mining dengan Algoritma C4.5 untuk Memprediksi Tingkat Kelulusan Mahasiswa. Jurnal ULTIMATICS - Vol. VI, No. 1, ISSN : 2085-4552.

[9] D. Alverina, A. R. Chrismanto, and R. G. Santosa. (2018), "Perbandingan Akurasi Algoritma C4.5 dan CART dalam Memprediksi Kategori Indeks Prestasi Mahasiswa," Jurnal Teknologi dan Sistem Komputer, vol. 6, no. 2,Apr. 2018. Doi: 10.14710/jtsiskom.6.2.2018.76-83. 